\title{
Implementasi Sistem Kendali MPPT Panel Surya Berbasis Algoritma Incremental Conductance
}

\author{
Gatot Santoso Putra ${ }^{1}$, dan Muldi Yuhendri ${ }^{2}$ \\ 1,2Jurusan Teknik Elektro, Fakultas Teknik Universitas Negeri Padang \\ Jl. Prof. Dr. Hamka Air Tawar, Padang, 25132 Indonesia \\ gatot.santoso1903@gmail.com¹, muldiy@ft.unp.ac.id ${ }^{2}$
}

\begin{abstract}
Solar power plant (PLTS) is a renewable energy power plant that is starting to develop in Indonesia as fossil energy is decreasing as the main energy source for electricity generation. This PLTS works by converting sunlight energy into electrical energy using solar panels. Increasing the efficiency of PLTS can be done by controlling the solar panels at their maximum power point. The maximum power point of the solar panels can be obtained by finding the maximum solar radiation or by controlling the output voltage of the solar panels at the maximum power point using a power converter. This research proposed a maximum power point of solar panels by regulate the output voltage using boost converter, which is also called the maximum power point tracking (MPPT). MPPT control system is proposed using an incremental conductance algorithm which is implemented using Arduino Mega 2560 programmed with Matlab simulink. MPPT control system is designed for four 50 WP solar panels connected in parallel. The experimental results show that the proposed MPPT control system with the incremental conductance algorithm is able to control the output power of the solar panels at the maximum point.
\end{abstract}

Keywords - Solar panel, PLTS, MPPT, incremental conductance, arduino mega.

\begin{abstract}
Abstrak - Pembangkit listrik tenaga surya (PLTS) adalah salah satu pembangkit listrik energi terbarukan yang mulai berkembang di indonesia seiring semakin berkurangnya energi fosil sebagai sumber energi utama pembangkit listrik. PLTS ini bekerja dengan mengkonversikan energi cahaya matahari menjadi energi listrik menggunakan panel surya. Peningkatan efisiensi PLTS dapat dilakukan dengan mengendalikan panel surya pada titik daya maksimum. Titik daya maksimum panel surya dapat diperoleh dengan mencari radiasi cahaya matahari maksimum atau dengan mengendalikan tegangan output panel surya pada titik daya maksimum menggunakan konverter daya. Penelitian ini mengusulkan pencarian titik daya maksimum panel surya dengan mengatur tegangan outputnya menggunakan konverter boost, yang disebut juga dengan Maksimum Power Point Tracking (MPPT). Sistem kendali MPPT diusulkan menggunakan algoritma incremental conductance yang diimplementasikan menggunakan arduino mega 2560 dan diprogram dengan software simulink matlab. Sistem kendali MPPT dirancang untuk 4 buah panel surya 50 WP yang dihubungkan secara paralel. Hasil eksperimen menunjukkan bahwa sistem kendali MPPT yang diusulkan dengan algoritma incremental conductance telah mampu mengendalikan daya output panel surya pada titik maksimum.
\end{abstract}

Kata kunci- Panel surya, PLTS, MPPT, incremental conductance, arduino mega .

\section{Pendahuluan}

Energi listrik merupakan sumber energi yang sangat dibutuhkan dan bermanfaat dalam kehidupan sehari - hari. Sehingga kebutuhan untuk mendapatkan energi listrik semakin lama semakin meningkat karena adanya peningkatan jumlah dari populasi manusia itu sendiri[1]. Oleh sebab itu, Perlunya energi terbarukan. Total kapasitas dari energi terbarukan terpasang di tahun 2011 hanya mencapai $1.21 \mathrm{GW}$ atau sekitar $4.2 \%$ dari total potensi[2]. Energi terbarukan yang dimaksud adalah energi yang mudah didapatkan dan ramah lingkungan seperti halnya energi surya. Pada saat sekarang ini pemafaatan energi surya sebagai penghasil energi listrik merupakan salah satu teknologi yang harus dikembangkan diindonesia. Energi cahaya matahari dirubah menjadi energi listrik dengan mempergunakan teknologi photovoltaic yang terbuat dari bahan semikonduktor lainnya, dan disebut dengan solar cell[3]. Salah satu kendala dalam menggunakan energi surya ini adalah besarnya energi surya tersebut tidak dapat dimaksimalkan secara baik dikarenakan daya keluaran dari panel surya bervariasi dan tidak maksimal. Oleh karena itu, perlunya mendapatkan daya keluaran yang optimal dari panel surya tersebut.

Maximum Power Point Tracking atau yang disingkat dengan sebutan MPPT adalah sebuah rangkaian dari devais elektronik yang dapat mengubah-ubah titik operasi pada panel surya[4]. Dalam sistem ini akan didapatkan daya keluaran panel surya yang optimal. Kemudian daya keluaran yang didapatkan akan dibandingkan dengan daya keluaran tanpa menggunakan sistem MPPT ini. Parameter yang menjadi acuan untuk mendapatkan daya yang optimal pada keluaran panel surya ini ialah nilai tegangan dan arus masukan dari panel surya dengan daya keluaran dari panel surya yang telah digabungkan dengan sistem MPPT tersebut. Pengaturan tegangan keluaran konverter untuk MPPT dapat dilakukan dengan menerapkan algoritma MPPT. Dalam penelitian ini dipilih algoritma Incremental conductance (IncCod) sebagai algoritma MPPT 
untuk mengatur tegangan keluaran boost konverter agar diperoleh daya output maksimum pada photovoltaic. Algoritma ini bekerja berdasarkan kurva karakteristik daya versus tegangan photovoltaic (kurva P-V). Algoritma ini adalah pengembangan dari algoritma $P \& O$ yang dimana titik maksimum daya berada pada titik perubahan daya per perubahan tegangan sama dengan nol [5]. Sistem ini menggunakan boost konverter yang berfungsi untuk menyalurkan daya ke beban dan juga mengatur tegangan keluaran dari panel surya untuk menjaga titik kerja panel surya tetap pada titik MPP. Jenis converter ini dipilih untuk mendapatkan tegangan beban yang sesuai dengan standar. Serta mikrokontroller sebagai pusat pengontrolan dalam sistem ini.

\section{Metode}

\section{A. Panel Surya}

Panel surya adalah divais semikonduktor yang mengkonversi langsung sinar matahari menjadi energi listrik. Fotovoltaic bukanlah sumber dari arus tetap atau sumber tegangan tetapi bisa juga diperkirakan sebagai generator arus dengan sumber tegangan yang berubah[6]. Secara sederhana panel surya terdiri dari persambungan bahan semikonduktor bertipe $\mathrm{p}$ dan $\mathrm{n}$ ( $\mathrm{p}-\mathrm{n}$ junction semiconductor) yang jika terkena sinar matahari maka akan terjadi aliran elektron, aliran elektron inilah yang disebut sebagai aliran arus listrik [7]. Proses pengubahan energi matahari menjadi energi listrik ditunjukkan dalam Gambar 1.

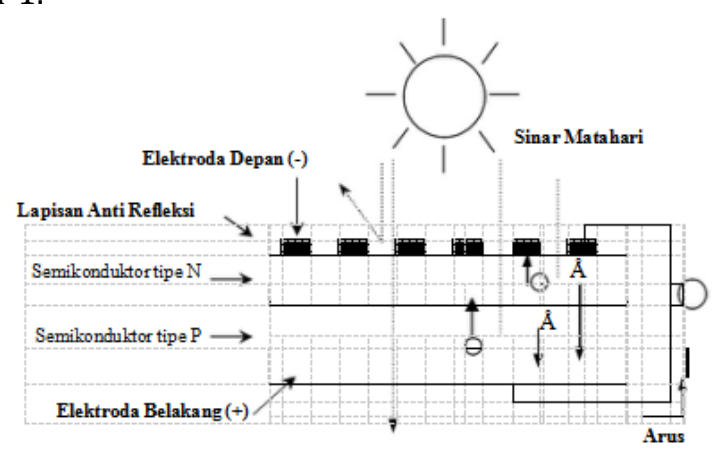

Gambar 1. Proses pengubahan energi matahari menjadi energi listrik.

Ketika sinar matahari yang terdiri dari photon-photon jatuh pada permukaaan bahan penyerap (absorber), akan diserap, dipantulkan, atau dilewatkan begitu saja. Jika cahaya matahari berupa photon melompati permukaan panel surya maka akan terjadi penumpukan elektron pada $\mathrm{P}-\mathrm{N}$ Junction. Jika lapisan silikon tipe $\mathrm{N}$ dan tipe $\mathrm{P}$ terhubung dengan beban luar, aliran elektron akan terjadi. Makin banyak photon yang melewati panel surya maka akan menghasilkan jumlah elektron yang semakin besar, dan hanya photon dengan tingkat energi tertentu yang akan membebaskan elektron dari ikatan atomnya, sehingga mengalirlah arus listrik. Panel surya mengubah poton dari cahaya matahari yang secara langsung menghantam permukaan menjadi listrik dengan tegangan dan arus karakteristik [8].

\section{B. Boost Konverter}

Boost Converter adalah salah satu DC-DC Converter yang digunakan untuk menstabilkan tegangan dengan menaikkan tegangan (Step-up) dimana tegangan keluaran (Vout) lebih tinggi dari pada tegangan masukan (Vin) tanpa harus menghilangkan daya yang cukup besar sehingga dapat mengatasi kekurangan tegangan. DC-DC Converter hanya mengubah level tegangan dan level arus keluaran DC tanpa mengubah daya selama proses konversi energi listriknya. Model switch DC-DC konverter beroperasi dengan menyimpan energi input sementara kemudian dilepasnya dalam bentuk tegangan atau arus pada level yang tidak sama [9]. Komponen utama pada Boost Converter ini adalah sumber tegangan input dc (Vd), penyaklar (S), diode freewheel (D), kapasitor filter (C), dan beban resistansi (R). Pengendalian DC-DC Converter dilakukan dengan memberikan sinyal yang mengatur waktu ON dan waktu OFF pada switch. Sinyal tegangan yang berfungsi untuk pengaturan switch biasanya menggunakan PWM (Pulse Width Modulation). Filter yang dibuat dengan induktor atau terkadang juga dengan kapasitor biasanya disimpan pada output dari konverter tersebut untuk mengurangi ripple tegangan. Gambar 2 menunjukan skema rangkaian boost converter yang digunakan untuk MPPT.

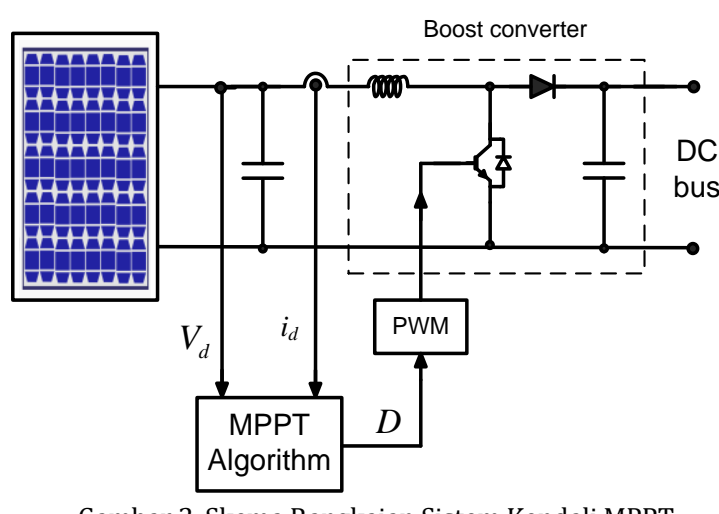

Gambar 2. Skema Rangkaian Sistem Kendali MPPT

Prinsip Kerja rangkaian ini adalah pada saat saklar dalam kondisi tertutup arus akan mengalir ke induktor sehingga menyebabkan energi yang tersimpan di induktor naik. Jika saklar dalam kondisi terbuka, arus induktor akan mengalir menuju beban melewati dioda sehingga energi yang tersimpan pada induktor akan turun. Boost converter bekerja dengan menghasilkan tegangan keluaran yang lebih tinggi dari tegangan masukannya. Besarnya tegangan Vout keluaran sama dengan perbandingan antara tegangan masukan (Vin) dengan 1 kurang duty cycle (D), seperti yang ditunjukan pada persamaan berikut,

$$
\mathrm{V}=\frac{\mathrm{Vd}}{1-\mathrm{D}}
$$




\section{Maximum Power Point Tracking (MPPT)}

Maximum Power Point Tracking (MPPT) merupakan salah satu cara untuk mendapatkan daya keluaran maksimum pada panel surya melalui pengaturan tegangan dan arus panel surya[11]. MPPT ini bekerja menggunakan DC-DC Converter untuk mengatur tegangan keluaran panel surya [12]. Pengaturan tegangan konverter untuk MPPT dilakukan dengan menggunakan algoritma MPPT. Algoritma MPPT yang diusulkan dalam penelitian ini adalah metode Incremental Inductance. Metode Incremental conductance didasarkan dengan kemiringan kurva daya dan tegangan Array PV dimana perubahan daya per perubahan tegangan bernilai nol pada saat MPP [13]-[15]. Metode ini bertujuan untuk meningkatkan akurasi pelacakan dan kerja dinamis dalam kondisi yang cepat berubah. Tegangan dan arus output panel surya selalu diperhatikan pada pengontrol MPPT yang bertujuan untuk dapat menghitung duty cycle apakah dinaikkan atau diturunkan. Gambar 3 menunjukan cara kerja algoritma Incremental conductance dalam mencari titik maksimum daya panel surya.

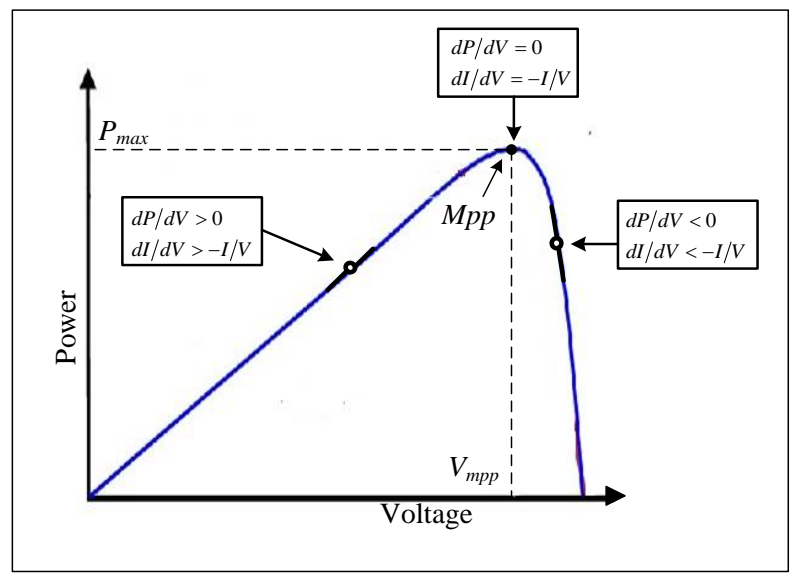

Gambar 3. Prinsip metode IncCod

Daya output pada Array PV dapat dihitung $\mathrm{P}=\mathrm{V} \times \mathrm{I}$ kemudian diturunkan menjadi :

$$
\frac{d V}{d P} \frac{d(V \times I)}{d V} I+V \frac{d I}{d V} \rightarrow \frac{1}{V} \times \frac{d P}{d V} \frac{1}{V}+\frac{d I}{d V}
$$

Dimana P, V, dan I merupakan daya, tegangan, dan arus. Tujuan dari algoritma ini adalah untuk menemukan titik operasi tegangan dimana konduktansi sesaat pada Array PV (I/V) sama dengan incremental conductance (dI/dV). Gambar 11 berikut menunjukan kurva kemiringan dari daya Array PV bernilai nol saat MPP, penambahan pada sisi kiri dan pengurangan pada sisi kanan dari MPP. Konsep ini dirumuskan dalam persamaan :

$$
\begin{aligned}
& \frac{\mathrm{dV}}{\mathrm{dP}} \quad 0 \text { jika } \frac{\mathrm{dI}}{\mathrm{dV}}-\frac{1}{\mathrm{~V}} \text { (pada MPP) } \\
& \frac{\mathrm{dV}}{\mathrm{dP}}>0 \text { jika } \frac{\mathrm{dI}}{\mathrm{dV}}>-\frac{1}{\mathrm{~V}} \text { (bagian kiri dari MPP) }
\end{aligned}
$$

$$
\frac{\mathrm{dV}}{\mathrm{dP}}<0 \text { jika } \frac{\mathrm{dI}}{\mathrm{dV}}<-\frac{1}{\mathrm{~V}} \text { (bagian kanan dari MPP) }
$$

Sistem kendali MPPT dengan menggunakan boost converter dirancang menggunakan Arduino mega 2560 sebagai kontrolernya yang diprogram langsung dengan menggunakan Simulink Matlab. Penelitian ini diimplementasikan pada panel surya 50WP sebanyak 4 buah panel surya. Gambar 4 menunjukan skema rangkaian elektronika yang digunakan untuk sistem kendali MPPT, yang terdiri rangkaian catu daya, arduino mega, sensor arus dan sensor tegangan.

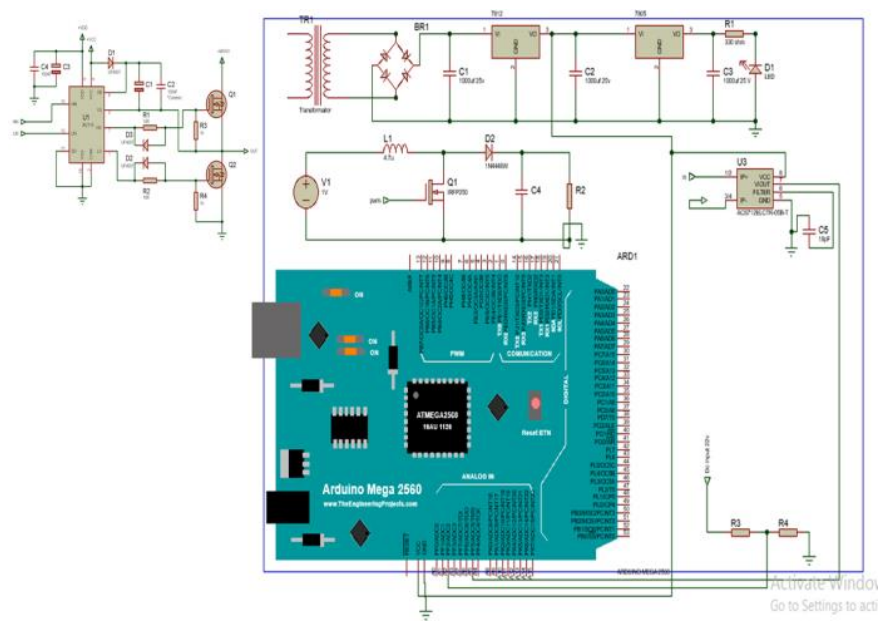

Gambar 4. Rangkaian Hardware Keseluruhan

\section{HASIL DAN PEMBAHASAN}

Hasil pembuatan hardware sistem kendali MPPT yang diusulkan dengan menggunakan boost konverter ditunjukan oleh Gambar 5. Hardware ini terdiri dari boost konverter, arduino mega 2560, sensor arus, sensor tegangan, power suply dan fan.

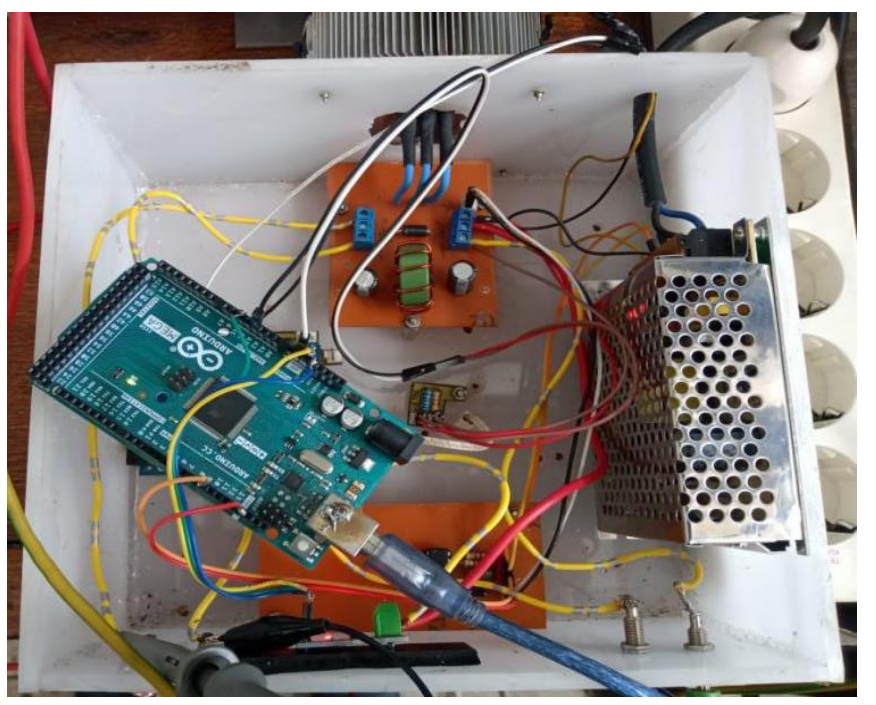

Gambar 5. Hardware Sistem 
Rangkaian sistem kendali MPPT yang ditunjukan pada Gambar 5 di atas dihubungkan dengan empat buah panel surya yang dipasang di samping laboratorium, seperti yang ditunjukan oleh Gambar 6.
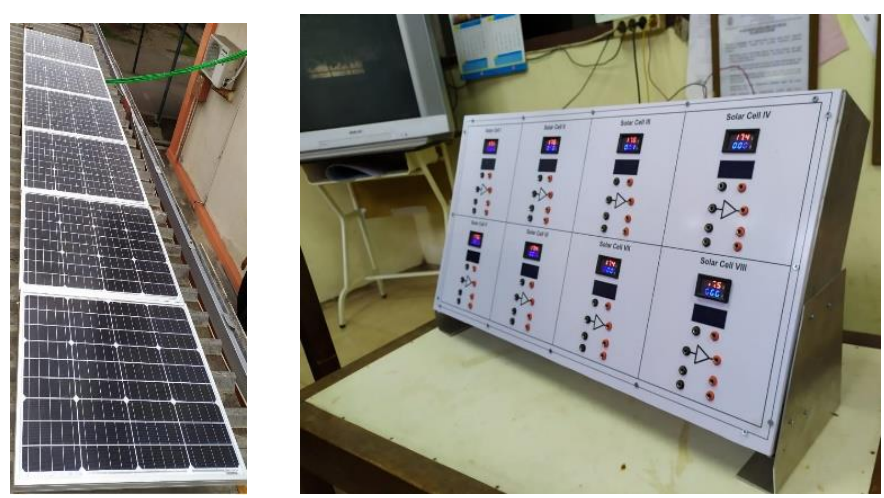

Gambar 6. Panel surya 50 WP

Sebelum dilakukan uji MPPT, terlebih dahulu dilakukan uji karakteristik panel surya yang digunakan dalam penelitian ini. Gambar 7 menunjukan kurva I-V dan kurva $\mathrm{P}-\mathrm{V}$ hasil pengujian panel surya yang dilakukan dalam penelitian ini.
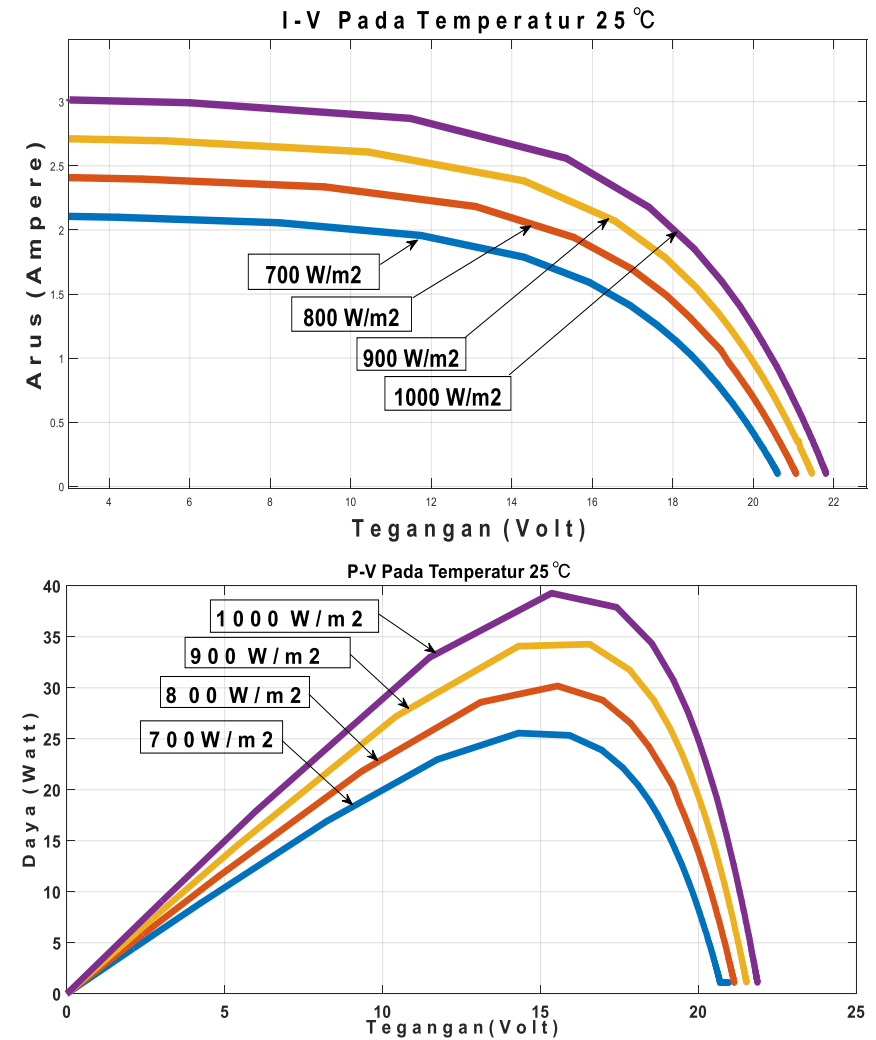

Gambar 7. Kurva I-V dan P-V panel surya 50 WP.

Gambar 7 menunjukan bahwa setiap perubahan radiasi cahaya matahari terdapat satu titik daya maksimum pada panel surya. Titik daya ini berada pada nilai tegangan berbeda. Untuk mendapatkan daya maksimum, maka tegangan panel surya perlu dikendalikan pada titik daya maksimum tersebut.

Selanjutnya dilakukan pengujian boost konverter untuk melihat kinerja dari alat tersebut. Gambar 8 sampai 10 menunjukan hasil pengujian boost konverter. Gambar 8 dan 10 menunjukan bahwa tegangan input konverter adalah 20,6 Volt, sedangkan tegangan outputnya adalah 52,5 Volt. Hasil ini menunjukan bahwa boost converter telah bekerja dengan baik, dimana tegangan outputnya lebih besar dari tegangan input.
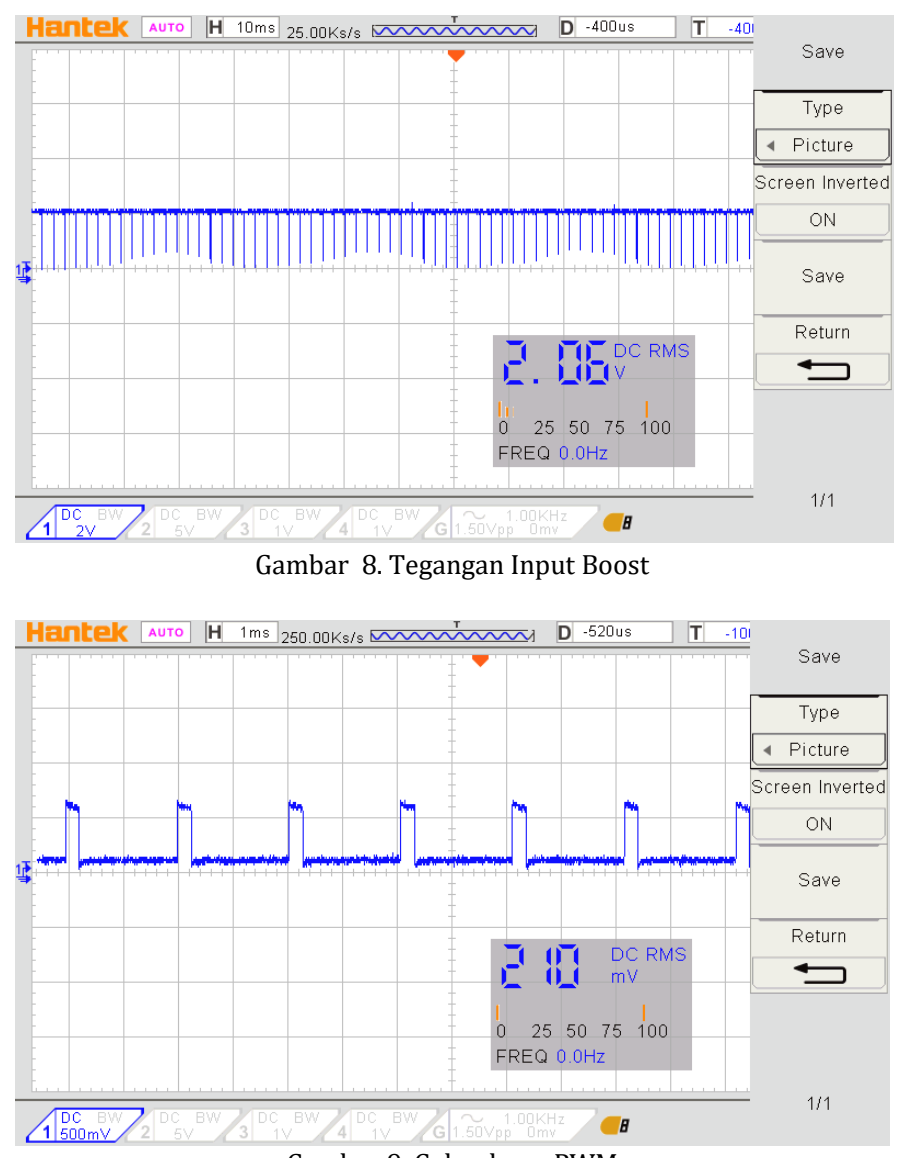

Gambar 9. Gelombang PWM

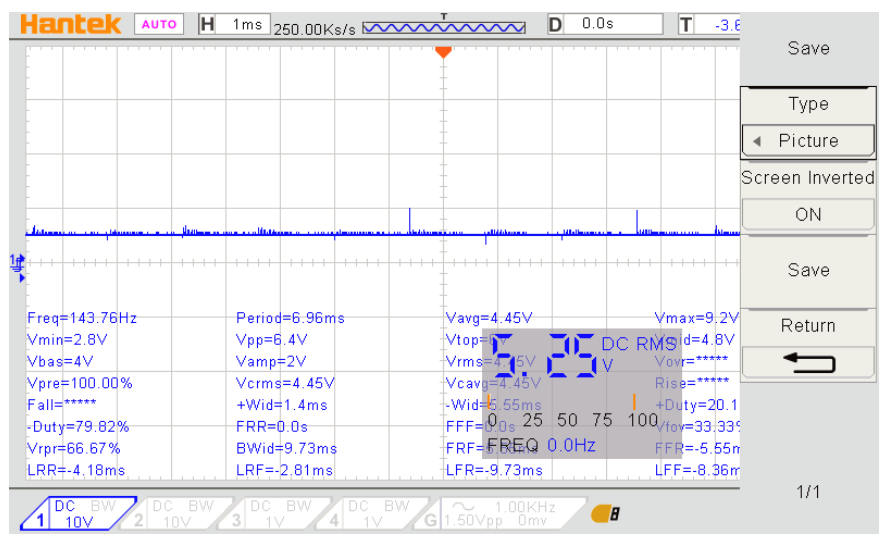

Gambar 10. Tegangan Output Boost Konverter 
Setelah boost konverter dinyatakan bekerja dengan baik, selanjutnya dilakukan ujicoba sistem kendali MPPT berbasis algoritma incremental conductance. Algoritma ini diimplementasikan dengan menggunakan simulink Matlab. Gambar 11 menunjukan bentuk program MPPT berbasis algoritma incremental conductance yang dibuat dalam simulink Matlab.

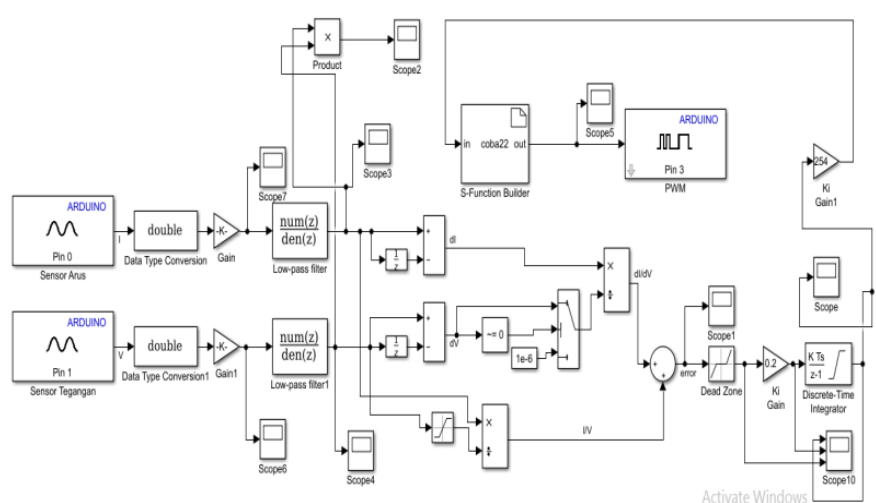

Gambar 11. Algoritma Incremental Conductance dalam simulink

Gambar 12 menunjukan instalasi hardware pengujian sistem kendali MPPT yang dilakukan di Laboratorium.

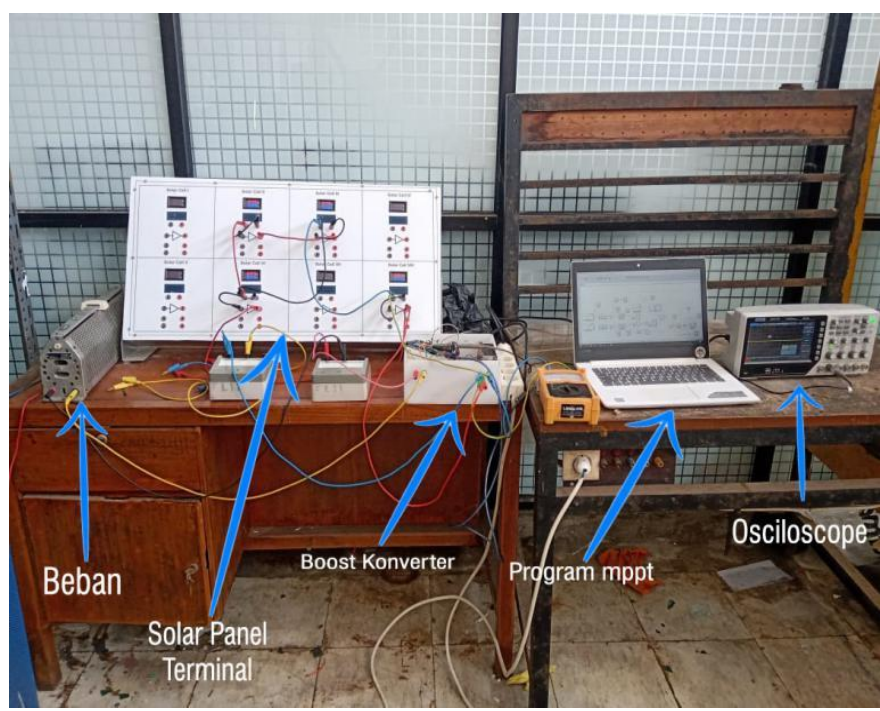

Gambar 12. Pengujian sistem kendali MPPT

Selanjutnya dilakukan uji sistem kendali MPPT untuk melihat daya keluaran panel surya. Pengujian dilakukan pada waktu jam 10.00 WIB Pagi dengan kondisi cuaca sedikit mendung. Dalam pengujian ini, empat buah panel surya 50 WP dihubungkan secara parallel. Sedangkan output boost konverter dihubungkan dengan beban resistor, seperti yang ditunjukan oleh Gambar 12. Dalam pengujian ini, grafik arus, tegangan dan daya panel surya dilihat melalui scope dalam simulink Matlab. Gambar 13 sampai 14 menunjukan hasil pengujian sistem kendali MPPT yang dilakukan.

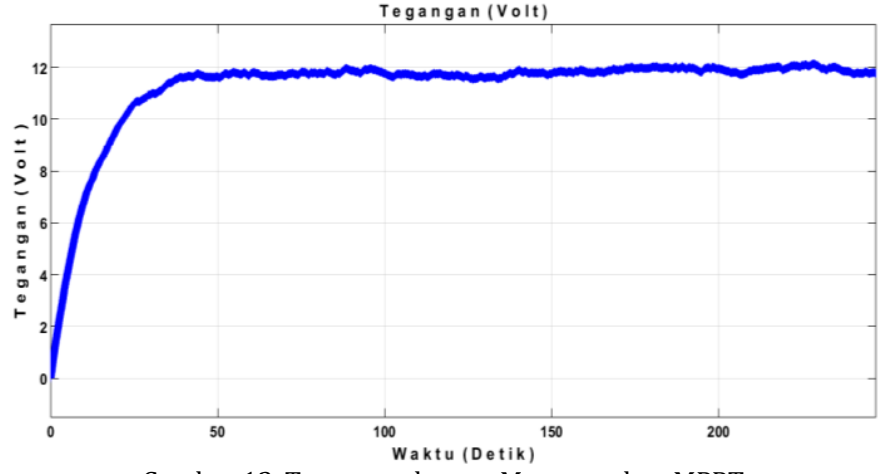

Gambar 13. Tegangan dengan Menggunakan MPPT

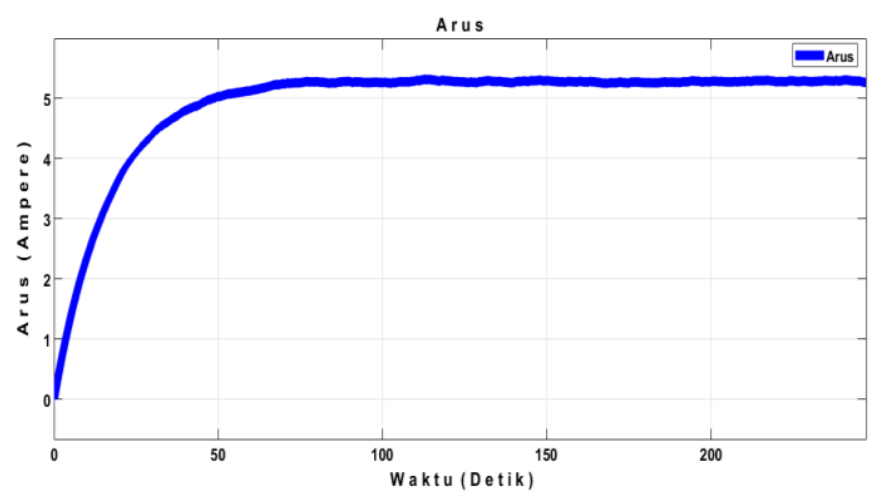

Gambar 14. Arus dengan Menggunakan MPPT

Daya

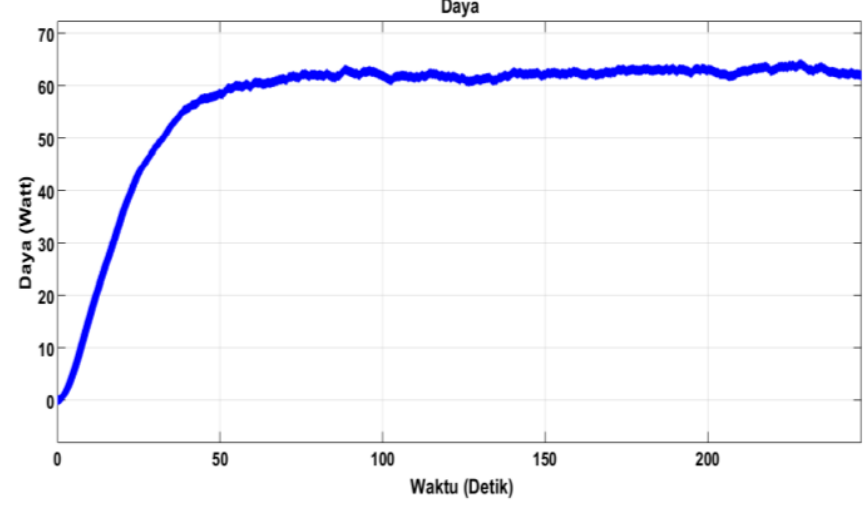

Gambar 15. Daya dengan Menggunakan MPPT

Gambar 15 menunjukan bahwa daya yang dihasilkan panel surya sekitar 60 Watt pada waktu tersebut. Gambar 13 dan 14 menunjukan perubahan nilai arus dan tegangan akibat pencarian titik daya maksimum oleh konverter boost. Hasil ini menunjukan bahwa konverter telah bekerja dengan baik dalam mengatur tegangan output panel surya pada titik daya maksimum.

\section{PENUTUP}

Penelitian ini mengusulkan sistem kendali MPPT untuk panel surya berbasis algoritma incremental conductance dengan menggunakan boost converter. Sistem kendali MPPT diimplementasikan dengan menggunakan arduino Mega 2560 yang diprogram dengan simulink Matlab. Sistem yang dirancang ini diujikan pada panel surya 50 WP sebanyak 4 buah. Hasil pengujian 
menunjukan bahwa sistem kendali MPPT yang diusulkan telah bekerja dengan baik, dimana alat yang dibuat telah dapat mengendalikan daya output panel surya pada titik pada maksimum.

\section{REFERENSI}

[1] A. Faizal and B. Setyaji, "Desain Maximum Power Point Tracking ( MPPT ) pada Panel Surya MenggunakanMetode Sliding Mode Control," vol. 14, no. 1, pp. 22-31, 2016.

[2] R. E. K. O. Caraka and P. C. Ekacitta, "Simulasi Kalkulator Energi Baru Terbarukan ( EBT ) Guna Memenuhi Ketahanan Energi di Indonesia," vol. 16, no. 2, pp. 77-88, 2016

[3] Ima Rochimawati, "Perancangan Pembangkit Listrik Tenaga Surya," Strateg. J. Tek. Ind., vol. 1, no. 1, pp. 169-180, 2019,

[4] I. Winarno and L. Natasari, "Maximum Power Point Tracker (MPPT) Berdasarkan Metode Perturb and Observe Dengan Sistem Tracking Panel Surya Single Axis," Umj, no. November, pp. 1-9, 2017.

[5] R. I. Putri, S. Wibowo, and M. Rifa'i, "Maximum power point tracking for photovoltaic using incremental conductance method," Energy Procedia, vol. 68, pp. 22-30, 2015,

[6] A. M. Atallah, A. Y. Abdelaziz, and R. S. Jumaah, "I Mplementation 0 F P Erturb a Nd O Bserve Mppt O F Pv S Ystem W Ith D Irect C Ontrol M Ethod U Sing B Uck a Nd B Uck - B Oost C Onverters," vol. 1, no. 1, 2014.

[7] Aswardi, M. Yuhendri dan D. T. Yanto, Teknik Elektronika Daya, Indonesia : IRDH Book Publisher, 2020.

[8] I. Technology and D. C. View, "Comparative Experimental Analysis with and without Proposed Algorithm for MPPT using a DC-DC Converter for PV Array Comparative Experimental Analysis with and without Proposed Algorithm for MPPT using a DC-DC Converter for PV Array," vol. 03, no. April, pp. 80-90, 2015.

[9] S. Utami, "Implementasi Algoritma Perturb and Observe untuk Mengoptimasi Daya Keluaran Solar Cell Menggunakan MPPT di Laboratorium Energi Baru Terbarukan," J. Infotel, vol. 9, no. 1, p. 92, 2017, doi: 10.20895/infotel.v9i1.165.

[10] M. Yuhendri, M. Ashari and M. H. Purnomo, "A Novel Sensorless MPPT Control For Wind Turbine Generators Using Very Sparse Matrix Converter Based on Hybrid Inteligent Control," Int. Review of Electrical Engineering (IREE), vol. 10, no. 2, pp. 233-243, March 2015.

[11] R. Fernandes dan M. Yuhendri, "Implementasi Solar Tracker Tanpa Sensor pada Panel Surya," JTEV, vol. 6, no. 2, pp. 337-343, 2020.

[12] F. Senrianokxi, "Rancang Bangun Modul Converter DC-DC Menggunakan Mikrokontroler Arduino Berbasis IoT Untuk Penelitian MPPT ( Maximum Power Point Tracking) Pada Panel Surya," 2020

[13] M. Yuhendri, Aswardi dan Hambali, "Implementasi Pompa Air Otomatis Tenaga Surya Untuk Rumah Ibadah," Jurnal Inovasi Hasil Pengabdian Masyarakat (JIPEMAS), vol. 3, no. 2, pp. 166-177, 2020.

[14] G. Wibisono, S. H. Pramono, and M. A. Muslim, "MPPT Menggunakan Metode Hibrid JST dan Algoritma Genetika Untuk Sistem Photovoltaic," J. EECCIS, vol. 8, no. 2, pp. 181-186, 2014.

[15] J. A. Hamonangan, "Review Perbandingan Teknik Maximum Power Point Tracker (MPPT) untuk Sistem Pengisian Daya menggunakan Sel Surya," J. Teknol. Dirgant., vol. 16, no. 2, p. 111, 2019, doi: 10.30536/j.jtd.2018.v16.a2998

\section{Biodata Penulis}

Gatot Santoson Putra, Tanjung Pauh Mudik, 19 Maret 1997 Menyelesaikan studi DIV Teknik Elektro Industri pada Jurusan Teknik Elektro Fakultas Teknik Universitas Negeri Padang.

Dr. Muldi Yuhendri, S.Pd, MT, lahir di Kampung Aur, 13 Desember 1981. Sarjana Pendidikan Teknik Elektro, Universitas Negeri Padang tahun 2005, S2 Teknik Elektro Sistem Tenaga, ITS tahun 2009, S3 Ilmu Teknik Elektro, ITS tahun 2017. Staf pengajar pada jurusan teknik elektro FT UNP sejak tahun 2006 sampai sekarang. 